\title{
IMPORTÂNCIA DOS ESPECTADORES, COMO FORMADORES DE AUDIÊNCIA, EM RELAÇÃO ÀS SUAS EXPECTATIVAS
}

Sidney Proetti*

Resumo: Este artigo tem por objetivo demonstrar a importância dos espectadores como formadores de opiniões, em relação às suas expectativas em um contexto de audiência nos meios de comunicação de massa. A abordagem se dá pela exposição, percepção e memorização seletiva em decorrência das atitudes comportamentais das pessoas. É um estudo de levantamento bibliográfico com análise da seguinte questão: “Como alcançar (ou ultrapassar) as expectativas dos receptores na comunicação?”.

\begin{abstract}
This article aims to demonstrate the importance of viewers as of opinion formers, with regard to their expectations in a context of audience in the mass media. The approach is by exposure, selective perception and memorization as a result of the behavioral attitudes of people. It is a literature study with analysis of the following question: "How to achieve (or exceed) the expectations of the receivers in communication?".
\end{abstract}

\section{Introdução}

Buscou-se estudar e demonstrar neste trabalho a importância dos espectadores, como formadores de audiência, em relação às suas expectativas. Para que se possa entender melhor a audiência, foram abordados subtemas como comunicação de massa, opinião pública, a influência dos meios de comunicação de massa, a influência dos líderes sobre a opinião pública, as fontes de resistência à mudança de opinião, os efeitos da comunicação de massa, abordagens sobre a persuasão, os fatores relativos à audiência quanto à exposição seletiva, a percepção seletiva, a memorização seletiva, a audiência e recepção com suas classificações de exposição, estrutural, usos e gratificações e perspectivas atitudinais, de persuasão, comportamentais, de condicionamento e da modelagem. Essas abordagens constam na primeira parte deste trabalho.

Sidney Proetti é Doutor em Comunicação Social, Mestre em Administração e autor de obras nas áreas de Administração, Marketing, Filosofia, Gestão Empresarial e Liderança. 
O enfoque central desta monografia encontra-se na segunda parte e destacou-se pelo estudo do seguinte problema: "Como alcançar (ou ultrapassar) as expectativas dos receptores na comunicação?” Não se propôs estudar de forma profunda ou esgotar esse tema-problema, pois seriam necessárias muito mais dedicação e pesquisas bibliográficas. Mas pode-se observar a relevância do assunto em questão por se tratar da observação da resposta dos receptores nas comunicações de massa.

Optou-se por adotar a pesquisa bibliográfica para o presente estudo, que, segundo Proetti (2006) “(...) faz-se uso dos materiais já publicados, escritos ou gravados mecânica ou eletronicamente, que contenham informações de diversas áreas (...)”, buscando-se fundamentações para o problema em questão. Para a construção deste trabalho, foram pesquisadas obras clássicas de autores como Joseph Luytem, José Marques de Melo, Antonio Carlos Ruótulo, Robert E. Lane, David O. Sear, Richard Dimbleby, Graeme Burton, Mauro Wolf, David K. Berlo e uma obra do próprio autor desta monografia.

Certamente, a questão de audiência será ainda muito estudada pelos alunos de pósgraduação e observada de modo científico pelos pesquisadores da ciência da comunicação social. Ela é o objetivo das redes de comunicação de massa e um grande desafio para aqueles que se dedicam ao seu estudo de modo racional. O entendimento das respostas dos receptores é um princípio que se faz necessário para, principalmente, poder melhorar a comunicação de massa. A partir da existência de audiência é que se tem o verdadeiro sentido de melhorar os processos de comunicação social.

\title{
PARTE I
}

\section{O líder de opinião: referencial teórico}

\begin{abstract}
Antigamente, pensava-se que, uma vez elaborada a mensagem para um determinado público visado, seria automática a sua recepção. Isso, no entanto, não se dá com tanta facilidade. Todo o ato comunicativo é, na realidade, uma tentativa de alguém atuar sobre um outro alguém, isto é, procurar modificar algo na estrutura mental da pessoa que recebe a mensagem... (LUYTEN, 1988, p. 10)
\end{abstract}

A citação acima expressa com clareza a preocupação do autor -Prof. Dr. Joseph M. Luyten para que se possa desenvolver a comunicação com eficácia. Não haveria razão para a existência de mensagens se não houvesse a intenção de comunicar algo a alguém. A estrutura que forma uma 
mensagem deve ser planejada de acordo com o que se deseja alcançar e, para isso, o raciocínio do emissor, na criação da mensagem, deverá ser percebido e entendido pelo receptor. Nesse contexto, é preciso que a fonte comunicadora encontre alguma forma de verificar se sua mensagem foi recebida e entendida pelo receptor e se a resposta -audiência - foi a esperada. Surge, então, uma terceira pessoa, a qual se denomina líder de opinião, que tem como função dar credibilidade ao comunicador e a sua mensagem.

É muito comum encontrar, nos grupos de pessoas, um indivíduo que se destaca e recebe crédito e apoio por sua opinião, que exerce influência nos demais membros do grupo, que o consultarão quando se fizer necessário para novas formações de opiniões. Para se entender melhor, pode-se pensar em um político, em um professor ou em um empresário de determinada cidade, alguém que tenha boa imagem pública, seja aceito como um líder de opinião para questões sociais e/ou locais e exerça influências sobre a formação da opinião da população local. Nesse sistema de comunicação popular, o líder de opinião é importante, pois há a interação dos grupos heterogêneos nas camadas sociais. O Prof. Dr. Joseph M. Luyten exemplifica isso da seguinte forma:

... nos lembramos da história da viagem do homem à Lua. No Nordeste brasileiro, muitas pessoas não acreditavam que isso fosse possível. No entanto, passaram a crer no fato somente depois que circularam alguns folhetos versando a respeito. Nesse caso, chamamos os poetas da literatura de cordel de opinião... (LUYTEN, 1998, p. 11)

O exemplo evidencia a posição dos poetas da literatura de cordel como líderes de opinião pública. Em qualquer área é possível encontrar líderes de opinião pública que se destacam pela facilidade de comunicação com grupos.

A comunicação de massa aproxima-se da comunicação popular relacionando-se pelos meios de comunicação pelas divulgações de assuntos de interesse do povo (LUYTEN, 1998, p. 40). Jornais, revistas, cinema, TV e rádio dedicam mais tempo à cultura popular, com participação sustentável, de forma econômica, dos anunciantes na comunicação de massa.

\section{A elite e os meios de comunicação}

Os meios de comunicação social constituem, paradoxalmente, meios de elite e de massas. Como instrumentos mecânicos e eletrônicos que difundem mensagens de acesso potencial a todos os indivíduos da sociedade, eles são meios que atingem as massas, atuando como intermediários entre elas e o mundo. Na verdade, é através da imprensa, do rádio, da TV e do cinema que os indivíduos se informam, cotidianamente, sobre os fatos da atualidade, se 
divertem, e se mantêm sintonizados com o meio-ambiente de que participam. (MELO, 1971, p. 11)

Os meios de comunicação são essenciais para a obtenção de audiência. Quanto maior acesso, de forma direta, a esses meios de comunicação, melhor será a capacidade de recepção da comunicação. Dessa forma, a sociedade está ao alcance dos meios de comunicação pelos meios informais - folk-comunicação - e pelos meios formais - eletrônicos e mecânicos - que atingem as massas e intermedeiam a sociedade com o mundo. Mesmo que os meios de comunicação atinjam as massas, formadas por público heterogêneo e anônimo, considerados como meios controlados pela elite $^{31}$, é importante ressaltar que as elites dirigentes dos meios de comunicação são os grupos fortes economicamente, como as organizações industriais e a classe política - Estado - que detêm o poder.

\title{
A linguagem das massas
}

\begin{abstract}
"Na verdade, toda a questão do crescimento da audiência de um canal de comunicação de massas reside na codificação das mensagens, ou melhor, na linguagem utilizada para transmitir as informações." (MELO, 1971, p. 22)
\end{abstract}

A citação acima fundamenta com exatidão a importância da codificação da(s) mensagem(s) a ser(em) enviada(s) para atender a intenção da fonte, pois todos os comportamentos racionais do emissor podem ser agregados para uma composição da mensagem de forma eficiente. Nesse contexto, existe a importância das experiências culturais, em especial a fala, do público receptor, ou seja, deve-se refletir sobre a condição de recepção de mensagens do receptor quando se elabora uma comunicação, obtendo-se, assim, mais fidelidade nesse processo. ${ }^{32}$ É fundamental que o agente comunicador - meio - (jornalista, escritor, rádio, $\mathrm{TV}$, etc.) se preocupe em planejar a linguagem comportamentos do emissor - em relação à linguagem falada - forma de recebimento/percepção das pessoas que vão receber a comunicação, pois proporcionará audiência.

Se o veículo de comunicação usa uma linguagem de difícil compreensão, mesmo que ele seja de fácil acesso, não permitirá o entendimento real e completo da mensagem e prejudicará a audiência esperada pelo emissor. Dessa forma, pode haver a retração do público e o consecutivo desinteresse, ocasionando a preferência por outros canais de comunicação e ocasionando a

\footnotetext{
${ }^{31}$ MELO, José Marques de. Comunicação, opinião, desenvolvimento, Rio de Janeiro: Vozes, 1971. p.12.

${ }^{32}$ BERLO, David K. O processo de comunicação: introdução à teoria e à prática. Trad. Jorge Arnaldo Fontes. São Paulo: Martins Fontes, 1999. p. 49.
} 
insatisfação dos receptores por não atender às suas expectativas. Essa ideia é reforçada com a citação a seguir, retirada da obra do Prof. Dr. José Marques de Melo:

... Nos Estados Unidos e em outros países mais desenvolvidos, os jornais diários e as agências informativas limitam a redação das notícias, das reportagens, dos editoriais ao idioma-básico da população, ao universo vocabular do leitor-médio. Fora dessas listas mínimas de palavras, nenhuma outra se emprega, sob pena de dificultar a legibilidade, de causar transtornos aos leitores na assimilação daqueles conteúdos em que estão especialmente interessados. Esse fenômeno reflete a natureza das organizações jornalísticas nesses países, onde o jornal é um produto de consumo de massas. Como tal, ele deve ser produzido, satisfazendo todos os anseios das massas de leitores. (MELO, 1971, p. 23)

Pode-se perceber no trecho "como tal, ele deve ser produzido, satisfazendo todos os anseios das massas de leitores", a preocupação do autor com a fidelidade da comunicação, pelo seu meio de transmissão, em relação à satisfação em decorrência do atendimento das expectativas dos leitores dos jornais, o que pode manter, aumentar ou até diminuir a audiência se a comunicação não for eficaz.

\section{Opinião pública}

Opinião Pública é uma das expressões mais conhecidas na sociedade contemporânea. Todavia, não goza de homogeneidade conceitual. Tem sido usada em diversas acepções, muitas vezes contraditórias e divergentes. (...) a Opinião Pública está sendo invocada constantemente para justificar revoluções, movimentos democráticos, explicar golpes de Estado e até apoiar ditaduras. (MELO, 1971, p. 49)

O estudo da Opinião Pública permite entender as manifestações da sociedade e colabora para explicar suas causas, dimensões e efeitos. O professor Dr. José Marques de Melo adotou duas orientações (MELO, 1971, p. 50) para conceituar Opinião Pública, que serão expressas abaixo, de modo individual:

- OPINIÃO: Juízo de valor, julgamento, tomada de posição, formulação de uma atitude;

Nesse contexto, forma-se o julgamento pela comparação de fatos e ideias com objetivo de escolha (conveniências vs. inconveniências). Para reforçar o entendimento e esclarecer o conceito de Juízo, cita-se:

O Juízo representa o ato de afirmação ou negação e compara idéias e coisas para julgá-las convenientes ou inconvenientes. É o pronunciamento das conveniências ou inconveniência entre duas idéias, o que demonstra o valor desse ato de intelectualidade... (PROETTI, 2003, p. 37) 


\section{- PÚBLICA: Da população, do povo, de modo geral.}

Nessa segunda orientação, deve-se pensar em grandes massas, em grande quantidade de pessoas com representatividade.

A Opinião Pública manifesta-se de forma objetiva, mas na sua essência ela é subjetiva, pois é formada a partir de situações objetivas, de fatos concretos com os quais os indivíduos se deparam com base na sua experiência perceptiva dentro do contexto social. A partir desse contexto, Marques de Melo expressa o conceito de Opinião Pública: “Opinião Pública - Juízo de valor formulado pelo povo em torno de um fato concreto".

É importante comentar que a Opinião Pública se expressa quando as pessoas possuem suas opiniões autoconscientes e manifestam sua liberdade de expressão e pensamento. Ela pode ser vista como a expressão e pensamento de uma sociedade em relação a um fato ou fenômeno; e um choque entre opiniões divergentes em relação a um fato em que haverá o predomínio de uma delas pelas preferências da maioria dos indivíduos. A apresentação da Opinião Pública de maneira explícita, pelas opiniões individuais das pessoas, confere a ela o caráter científico, pois as opiniões individuais são quantificadas para que se possa definir a tendência majoritária, ou seja, a maior preferência e opinião sobre um determinado fato.

Existe um elemento eficaz utilizado como ferramenta para verificar a Opinião Pública: a sondagem ou pesquisa cientifica. A sondagem observa e capta as opiniões individuais de uma amostra que represente a totalidade de uma população e se utiliza da matemática e da estatística, selecionando uma determinada quantidade de pessoas, para definir as tendências majoritárias, que são os critérios objetivos para formar a Opinião Pública. O instituto Gallup, fundado em 1934 nos Estados Unidos da América, foi um dos pioneiros na pesquisa de Opinião Pública e demonstrava, desde a sua fundação, a identificação de seus fenômenos para orientar os trabalhos dos profissionais da comunicação de massa. Gallup criou procedimentos metodológicos operacionais para a pesquisa de opinião visando obter mensurações da Opinião Pública que ajudavam, e ajudam ainda na atualidade, a recolher opiniões que repercutem nas tendências predominantes.

\section{A influência dos meios de comunicação de massa}


O ser humano transmite informações de geração a geração com a troca de experiências acumuladas empírica ou cientificamente. As informações que atingem a massa são difundidas pelos meios de comunicação e redifundidas/reenviadas pela própria massa. Começa-se, então, a concepção de opiniões predominantes - Opinião Pública - como produto de atividades sociais. A citação a seguir fundamenta essa ideia:

“...O processo de formação da Opinião Pública envolve todo um complexo de circulação das informações na comunidade...” (MELO, 1971, p. 58)

Dessa forma, a apreensão da ideia sobre um fato faz com que haja o juízo sobre o valor dela e desencadeie o raciocínio que levará à adoção, ou não, de opiniões individuais que, na somatória, formam a Opinião Pública.

Os meios de comunicação difundem os fatos que são objetos de verificação das pessoas que formam a massa crítica e sobre as quais vão formular juízos de valor para, consequentemente, expressar a opinião. A massa, por sua vez, forma grupos de valores familiares, intelectuais, empresariais e demais grupos da sociedade que tomam posições próprias e exercem pressões. Também difundem fatos para que as pessoas - massa - possam formular juízos de valor. Os grupos de pressão estimulam a atenção das pessoas - sociedade - e orientam a Opinião Pública em um determinado sentido. A propaganda tenta a persuasão das pessoas para que mudem de atitude ou conservem os padrões existentes. É nesse contexto que se insere o problema estudado neste trabalho, sendo ele: "como alcançar (ou ultrapassar) as expectativas dos receptores em uma comunicação?". Como se têm esses diferentes fatores complementares da Opinião Pública, as expectativas podem ser alcançadas se os ouvintes - audiência - tiverem suas atenções presas direcionadas - às mensagens, caso essas consigam por assim fazer. Tratar-se-á, na maioria dos casos, de fatos hipotéticos.

\section{Influência dos líderes sobre a opinião pública}

“... Como audiência para as tentativas de persuasão, o público em geral distingue-se, na sua maior parte, por um interesse relativamente modesto em matérias políticas e por níveis relativamente baixos de informação. Além disso, muitas das tentativas persuasivas que nos interessam têm de ser realizadas a distância, através de mensagens pela televisão e rádio, ou de relatos na imprensa..." (SEARS e LANE, 1966, p. 77) 
Fora dos meios de comunicação como o rádio, a TV e os jornais, há, ocasionalmente, a tentativa de influência de forma personalizada como, por exemplo, discurso em assembleia local, comício político e tentativas de influência pessoal por líderes de opinião. Qualquer que seja a situação de influência, uma determinada fonte procura persuadir - exercer influência -determinado público para que adote uma específica posição. Os influenciados poderão, ou não, aceitar essa posição. Quando há, em uma determinada situação, influência simples, existe nos influenciados três grupos básicos de cognição ou pensamentos: "sua avaliação da fonte, seu julgamento sobre a posição da fonte e sua própria opinião sobre o assunto ou problema em referência" (SEARS e LANE, 1966, p. 78).

\section{Avaliação da fonte de influência}

Nessa avaliação, procura-se saber se a pessoa influenciada tem sentimento positivo ou negativo em relação à fonte e com que intensidade o manifesta e sente. Avaliam-se, também, a idoneidade e a credibilidade que a pessoa que sofre a influência sente na fonte.

\section{Julgamento da posição da fonte}

Nesse caso, considera-se o julgamento que o influenciado formula a respeito da posição mantida pela fonte, ou seja, como a pessoa influenciada comporta-se em relação à posição da fonte sobre determinado fato.

\section{A opinião própria do influenciado}

Aqui, faz-se um esforço para modificar todo um conjunto de opiniões que é mantido por uma influência.

\section{Fontes de resistência à mudança de opinião}

Por que uma pessoa, sob tensões provocadas pela dissonância, não muda simplesmente de opinião sobre o assunto e dá o caso por encerrado? A razão é que existem preços ou resistências de várias espécies em tais mudanças de opinião... (SEARS e LANE, 1966, p. 93) 
Várias razões podem levar uma pessoa a oferecer resistência em modificar sua opinião como, por exemplo: a opinião foi testada pela experiência da pessoa; há outra fonte com mais autoridade que a pessoa aprecia; a opinião está apoiada na filiação grupal apreciada pela pessoa; quando a reputação está em jogo; a opinião serve uma determinada função social e econômica para o indivíduo; a opinião oferece um alvo legítimo para a agressividade da pessoa; a opinião dá uma base ética e explica as suas dificuldades e denigre a imagem dos seus críticos. Essas razões fazem com que os poderes de persuasão da massa por um líder político ou jornal tornem-se pequenos. Esses fatores reduzem as possibilidades de controle de opinião numa sociedade livre.

\section{Uma sociedade de comunicação de massa}

A vida em sociedade tornou-se dependente dos meios de comunicação de massa. A televisão, o rádio, o telefone são elementos naturais na vida cotidiana, assim como outros equipamentos de alta tecnologia como redes de computadores. Tudo isso modificou a vida no trabalho, nas escolas e no entretenimento.

\section{O que se quer dizer com massa?}

Pode-se falar sobre sistemas ou produto ou audiência. Podemos definir "massa", principalmente em termos de volume, escala e velocidade...(DIMBLEBY e BURTON, 1990, p. 161)

Entende-se por sistema a organização que gera a comunicação como, por exemplo, uma rede de rádio. O produto é o objeto transmitido pelo sistema como um jornal ou um programa de rádio e TV. Os produtos são manufaturados. A audiência pode atingir milhares ou milhões de pessoas que possuem pouco ou interesse comum apesar do fato de assistirem ao mesmo programa. A produção em massa de mensagens significa, também, a repetição em massa das próprias mensagens, pois tem como principal característica a operação em larga escala.

Richard Dimbleby e Graeme Burton (1990, p. 161) afirmam em sua obra que antes de se olhar para a sociedade de mídia e suas operações com maior detalhe, é preciso encará-las de forma crítica, pois dizem o mesmo tipo de coisas ao mesmo tempo com frequência - repetição da mensagem - além de verificar a questão de sua simultaneidade de penetração, por exemplo, como 
as mensagens transmitidas por rádio penetram diretamente nos carros e nos lares. Dessa forma, é necessário que se dê atenção, por parte de quem envia uma mensagem, ao seu significado, porque a emitiu e com que objetivos.

A mídia - meio - ajuda a criar a realidade do mundo, pois o ser humano forma uma sociedade de comunicação de massa, e essa comunicação integra e ajuda nas suas atividades de trabalho e lazer. A força motora da comunicação de massa geralmente é comercial e ajuda as empresas a desempenharem suas tarefas de comunicação de forma mais eficaz e econômica. Os efeitos da comunicação de massa ultrapassam seus lucros. O negócio da comunicação, incluindo a propaganda, envolve altos investimentos financeiros e grande número de pessoas. Sem os cuidados e planejamentos adequados, poderia levar o processo ao caos e a economia entraria em colapso. Outro aspecto relevante é o de que a mídia modela a sociedade pela sua capacidade de reproduzir mensagens, pois se ela afirma que se vive, na atualidade, uma sociedade moderna, é exatamente isso que pensa seu público. Ela ajuda a criar uma visão do mundo - cognição - pela percepção da sociedade como um todo.

\section{A mídia: poder e influência na sociedade}

A extensão das operações de comunicação da mídia exerce poder e influência que não são facilmente mensuráveis. Nas discussões sobre os efeitos/impactos da mídia, as principais questões referem-se à apresentação da violência e de tramas políticas. Na política, os líderes transformam-se em personalidades de mídia e representam atitudes específicas e crenças. Sua influência depende em grande parte do poder da mídia. A citação a seguir expõe interessantes informações:

$\mathrm{Na}$ Inglaterra, a televisão tem o poder de atingir 18 milhões de telespectadores no horário nobre. Cada um dos três mais populares jornais ingleses tem o poder de enviar 3 milhões e 500 mil mensagens idênticas todos os dias... (DIMBLEBY e BURTON, 1990, p.168)

Esses números impressionam, pois possibilitam imaginar a força da mídia num país com alto grau de importância na Europa. Esse fato permite refletir sobre o atingimento da mídia televisiva no Brasil, na atualidade, com uma população aproximada de 170 milhões de habitantes (conforme Censo Demográfico 2000 - IBGE). O efeito desse poder é difícil de ser mensurado, mas, provavelmente, deve ser bem maior em relação à Inglaterra. Isso prova que se vive hoje em uma sociedade de massa e esta se transforma de maneira contínua. A comunicação de massa é parte 
essencial da sociedade e a ajuda a definir sua visão e entendimento do mundo. A figura a seguir demonstra o processo de comunicação de massa.

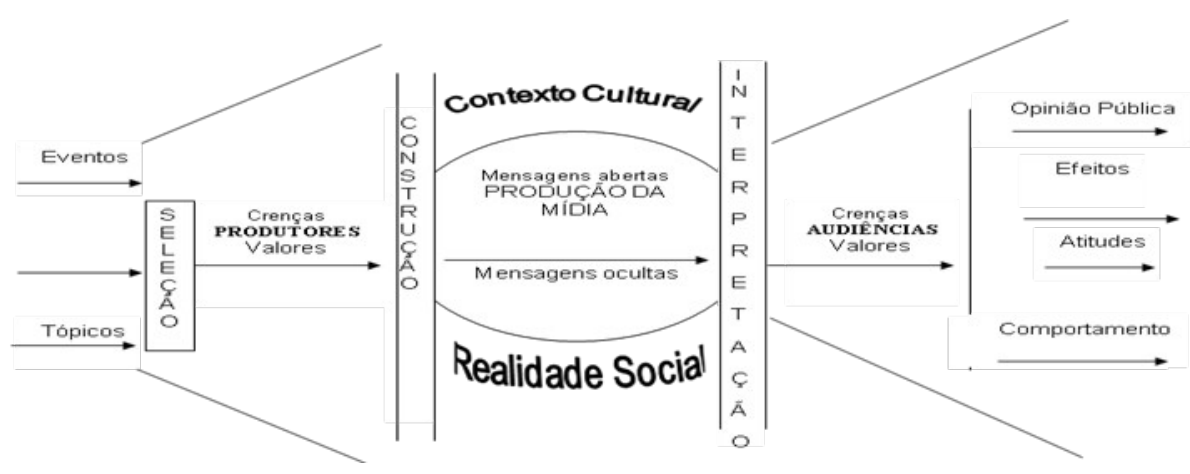

Figura 1 - O Processo de Comunicação de Massa

\section{Interpretando a mídia}

(...) Muitos materiais da mídia de massas, especialmente os de diversão, tendem a comunicar um ponto de vista limitado das pessoas. Repetem certos tipos de programas e certos tipos de pessoas... (DIMBLEBY e BURTON, 1990, p. 171)

Por mais que se tente formular ideias claras, depara-se com os limites de interpretação das pessoas receptoras. É preciso perceber que as limitações existem de ambos os lados - mídia e receptores - e entender que a visão de mundo da massa é limitada e, até certo ponto, distorcida. Quando se reconhece a existência desse problema, abre-se caminho para estudá-lo, entendê-lo e corrigi-lo.

Não existe, nos meios de comunicação, o monopólio das generalizações sobre a massa, mas, sim, operações e repetições constantes para atingi-la, pois a audiência é limitada. Para se interpretar a mídia, é necessário conhecer alguns de seus termos/conceitos: a edição, que se refere ao fato de se trabalhar os materiais, fatos e acontecimentos, coletados pelos especialistas de mídia; a seleção e construção, que concluem que toda mídia é o resultado de um processo no qual se reúnem alguns itens e outros são deixados de fora. A ideia de produto é ligada ao fato de que se produz o material da mídia em massa. A propriedade e dinheiro originam-se dos empresários e financistas que pagam as mensagens que querem transmitir; pagam as operações de comunicação. No final das contas, o pagamento, em casos de publicidade, é feito pela audiência. Há, também, a ideia de valores abertos 
e encobertos nas mensagens que se referem pelo fato de que, intencionalmente ou não, nenhuma mensagem chega ao público em primeira mão, possibilitando-se esconder o núcleo do fato. Esse fato pode ser sobre valores, crenças e opiniões. Tem-se, ainda, a ideia de estereótipos que são criados através de constante repetição. As pessoas, suas crenças e atitudes são apresentadas de forma simplificada e mistificada pela mídia, tornando-se fáceis de entender, mas podem encorajar preconceitos e falsos entendimentos. E, por último, tem-se a ideia de gênero, em que certos tipos de materiais de mídia já são convencionados por histórias de fácil reconhecimento por intermédio de tipos já convencionados que repetem os mesmos elementos e situações. É necessário que se olhe de forma crítica para esse tipo de comunicação, pois pode conter mensagens encobertas e que exercem grande influência. A figura $\mathrm{n}^{\circ} 2$ apresenta os elementos do processo da mídia:

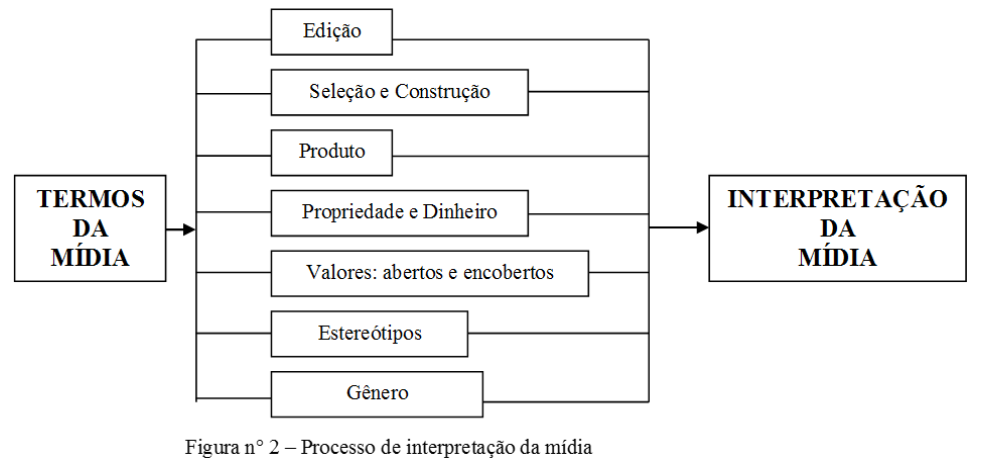

\section{Efeitos na comunicação de massa}

As tecnologias modernas ampliaram o alcance dos meios de comunicação de massa e possibilitaram o envio de mensagens para qualquer parte do mundo. $\mathrm{O}$ desenvolvimento do sistema telefônico, que interliga satélites e cabos, possibilita o processo de conexão baseado em computadores com o uso de linguagem numérica, caracterizando a informação digital. Essa característica se estende para o serviço eletrônico, que liga os usuários de computadores de todo o planeta, permitindo que eles troquem cartas eletrônicas de forma instantânea. Isso mudou os métodos de produção dos meios de comunicação de massa, deixando-a mais barata e mais rápida, além de ampliar sua qualidade produtiva.

A transmissão dos jornais eletrônicos já se torna possível e atinge as pessoas com fotos coloridas e ilustrações que enriquecem as mensagens dos textos. Os jornais, por intermédio dos seus 
agentes, colhem informações em qualquer parte dos continentes e as transmitem para suas redações para serem impressas.

As modernas tecnologias dos meios de comunicação de massa facilitam o alcance da audiência, pois fornecem mais informações de forma rápida e econômica. Quantidades maiores de informações podem ser transmitidas a grandes massas de receptores como se pode observar, a seguir, com a afirmação de Dimbleby e Burton:

\begin{abstract}
A tecnologia moderna trouxe novos métodos de distribuição de materiais para a audiência em termos de produto, isso significa que é possível alcançar os maiores e mais distantes mercados. Por exemplo, filmes podem ser distribuídos por cabo, tanto na Inglaterra como nos Estados Unidos ou, ainda, através de novos aparelhos, como videocassetes, hoje implantados em todo o mundo. (...) A nova tecnologia alargou a audiência. Criou novos produtos que são produzidos em massa... (DIMBLEBY e BURTON, 1990, p. 202)
\end{abstract}

A velocidade e a quantidade de informações permitem que a mídia afete a massa, direta ou indiretamente, nos lares e ambientes de trabalho em qualquer localidade e momento. Entenda-se "afetar" como a influência exercida para a audiência conquistada. A atualidade global é de uma sociedade rodeada de informações, sejam elas científicas, publicitárias, políticas, econômicas, cotidianas ou para entretenimento. Nem sempre o que se espera - expectativa - é recebido pelo receptor. Em plena era da informação, o que se percebe é uma invasão domiciliar e do ambiente de trabalho de informações de todos os tipos. O tema-problema deste trabalho centra-se exatamente nesse contexto, pois muitas tentativas veem-se frustradas e o público não se sente satisfeito com o que tem recebido de informações. Por mais que se esforcem, os meios de comunicação não conseguem $100 \%$ de aceitação das mensagens transmitidas. Isso se dá por ineficácia do conteúdo da mensagem ou por parte do receptor, pela sua limitação em decodificar ou, até, pela sua insatisfação pela forma de transmissão e abordagem.

É muito comum, quando se fala de cinema ou filmes alugados em videolocadoras, ter a expectativa frustrada, pois o trailer demonstrava grande produção criativa e artística e quando o filme é visto, na íntegra, o receptor demonstra descontentamento e diz: "o anúncio - trailer - era melhor que o filme". Essa expectativa frustrada estende-se, também, para outros produtos, como bens de consumo, cursos, políticos eleitos, empregos, professores, entre outros. Às vezes, empregam-se mensagens que vendem uma imagem, mas quando consumido o produto - bem ou serviço - ocorre o descontentamento por parte da audiência, ou seja, recebeu-se menos do que se esperava. 
É indiscutível o poder de informação em decorrência da estruturação e desenvolvimento do sistema de comunicação de massa, da mídia e de seus produtos. A propaganda se utiliza de estereótipos que transmitem mensagens e valores abertamente, criando realidades alternativas para o consumo de bens e serviços. A comunicação visual é um meio com grande domínio nos meios de comunicação, significa a representação de imagens - fotografia e outras formas de exposição - que se mostra por meio de signos definidos de acordo com a posição da câmera em relação ao espectador. As imagens contribuem para socializar as crenças e os valores que norteiam a sociedade constituída pela massa. As imagens são importantes instrumentos que complementam as notícias que levam informações sobre os fatos e contribuem para a cognição das pessoas - como veem e conhecem o mundo em que vivem - e, consecutivamente, constroem a realidade desse mundo. Todos esses aspectos e produtos aumentam o raio de ação da mídia, assim como seus métodos de produção e distribuição de mensagens, possibilitando o aumento da audiência em relação às expectativas dos ouvintes. As novas tecnologias eletrônicas reforçam o poder da capacidade de trocar e estocar informações e, nesse contexto, permitem e beneficiam o atingimento de se alcançar as expectativas dos receptores da massa. A figura $n^{\circ} 3$ a seguir contribui para a melhor visualização do uso das novas tecnologias eletrônicas para a comunicação de massa em relação à audiência.

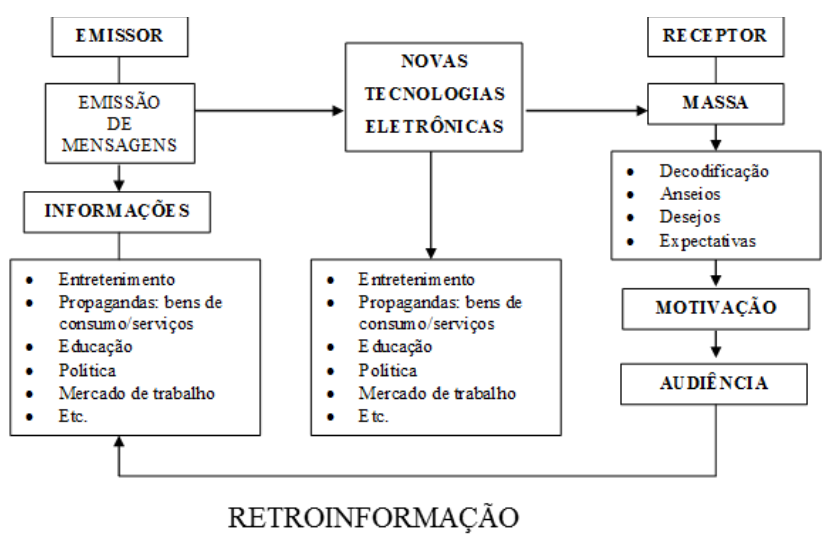

Figura $n^{\circ} 3$ - Processo de comunicação pelas novas tecnologias eletrônicas em relação às expectativas do receptor (massa) 


\title{
Uma abordagem sobre persuasão
}

\begin{abstract}
A $<<$ teoria $>>$ dos meios de comunicação resultante dos estudos psicológicos experimentais consiste, sobretudo, na revisão do processo comunicativo entendido como uma relação mecanicista e imediata entre estímulo e resposta, o que torna evidente, pela primeira vez na pesquisa sobre o mass media, a complexidade dos elementos que entram em jogo na relação entre emissor, mensagem e destinatário. A abordagem deixa de ser global, incidindo sobre todo o universo dos meios de comunicação e passa a $<<$ apontar $>>$, por um lado, para o estudo da sua eficácia persuasiva óptima e, por outro lado, para a explicação do $<<$ insucesso $>>$ das tentativas de persuasão... (WOLF, 1985, p. 28)
\end{abstract}

Mauro Wolf, 1985, deixa clara a importância dos meios de comunicação em relação à eficácia das mensagens para se obter a persuasão. A adequação das mensagens para os objetivos que se desejam alcançar está diretamente relacionada à estrutura da mensagem formulada pelo emissor e ao uso dos meios de comunicação. É possível que haja persuasão dos destinatários - receptores - se a forma e a organização das mensagens forem adequadas às ideias pessoais que se deseja enviar. Assim, é essencial que o emissor interprete as próprias mensagens. Isso demonstra que essas mensagens contêm características particulares que fazem parte do estímulo que interage com a personalidade do emissor em relação à personalidade do público que vai receber as mensagens. Os efeitos são variáveis de indivíduo para indivíduo. Isso ocorre porque existem particularidades específicas. (Ver figura $\mathrm{n}^{\circ} 4$ a seguir)

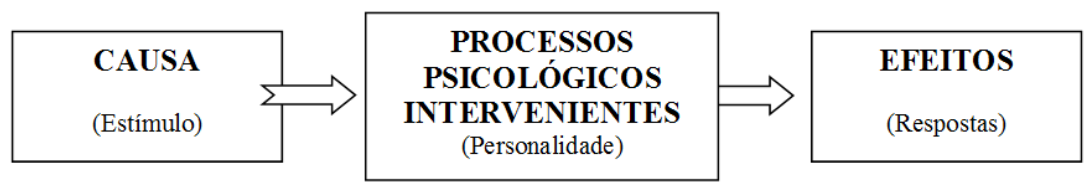

Figura ${ }^{\circ} 4$ - Estímulo e resposta no processo de persuasão: Teoria Hipodérmica

\section{Os fatores relativos à audiência}

A partir deste item serão expostos e tratados temas que contribuirão para o entendimento do problema central deste trabalho, norteado pela pergunta: "Como alcançar (ou ultrapassar) as expectativas dos receptores numa comunicação". 
A relação entre as informações apresentadas numa campanha informativa e a absorção por parte do público das mensagens dependem de algumas características psicológicas da própria audiência: o interesse em obter informação, a exposição seletiva provocada pelas atitudes já existentes, a interpretação seletiva e a memorização seletiva.

\section{$O$ interesse em obter informação}

O interesse e a motivação por parte de um público em obter informações sobre uma campanha estão relacionados com a falta de conhecimento sobre os assuntos tratados. Essa falta de conhecimento é exatamente o que torna difícil de atingir essa parcela de público não-informado. Existem alguns motivos que podem ser as causas da origem dessa situação como, por exemplo, a escassez de interesse e de motivação por determinados temas, dificuldade de acesso à informação e, também, pode-se considerar a apatia social. Esses fatores podem, ainda, estar relacionados entre si.

Quanto mais expostas as pessoas ficarem a um assunto, maior a possibilidade de seus interesses em relação a ele aumentarem; e quanto maior o interesse, mais motivadas se sentem para aumentar seus conhecimentos sobre ele.

\section{A exposição seletiva}

As preferências das diferentes camadas da população em relação aos meios de comunicação são de fundamental importância para a obtenção de audiência. O público poderá se expor caso haja interesse pela campanha educacional ou qualquer exposição efetuada pelos meios de comunicação, pois grande parte do efeito de qualquer campanha informativa será predeterminado pela forma como se estruturará a audiência.

A massa poderá expor-se à informação se estiver de acordo, de modo individual, com as atitudes das mensagens; porém, a evitará se algo na estrutura das mensagens desagradá-la. Uma campanha de persuasão será acolhida pelos indivíduos se os mesmos já estiverem de acordo com as opiniões apresentadas e se sensibilizarem novamente.

\section{A percepção seletiva}


Os elementos do público não se expõem ao rádio, à televisão ou ao jornal num estado de nudez psicológica; pelo contrário, apresentam-se revestidos e protegidos por predisposições já existentes, por processos seletivos e por outros fatores. (KLAPER, 1963, p. 247 in WOLF, 1985, p. 33)

Essa citação confirma a percepção seletiva humana que estabelece critérios de seleção do que lhe interessa e deseja obter. A interpretação de cada indivíduo pode transformar e adaptar as mensagens recebidas fixando-as aos seus valores em relação aos valores e atitudes do emissor. Outro mecanismo de percepção seletiva se dá pelos efeitos de assimilação ou contraste. A assimilação existirá quando o receptor considerar as opiniões expressas nas mensagens como semelhantes às suas, e o contraste ocorrerá se as opiniões não forem análogas.

\section{A memorização seletiva}

A memorização das mensagens baseia-se em elementos de seletividade que se assemelham se houver aspectos semelhantes e que estejam de acordo com as atitudes e as opiniões próprias dos indivíduos - receptores. As mensagens serão memorizadas em um grau mais elevado do que outros assuntos e isso se acentuará à medida que aumentar o tempo de exposição dos indivíduos em relação às mensagens, pois a memorização seletiva se concretiza em relação ao tempo de contato com as mensagens mais significativas para o indivíduo em detrimento dos mais discordantes ou que culturalmente não interessam.

\section{Audiência e recepção}

A comunicação social, de forma geral, estuda a audiência e recepção em suas pesquisas de cunho acadêmico. Assim também fazem os profissionais dos meios de comunicação que focam sua atenção para entender o comportamento dos receptores das mensagens transmitidas pelas novas tecnologias. O Prof. Dr. Antonio Carlos Ruótulo define a audiência como:

A audiência dentro do processo de comunicação pode ser definida como o conjunto de respostas dos receptores aos conteúdos dos meios de comunicação social. Essas respostas podem ser internas (como uma mudança de opinião) ou externas (como a compra de um produto). A audiência em si é um conjunto de pessoas anônimas, heterogêneas, distribuídas 
com ampla dispersão geográfica em seu contato entre si ou com o comunicador. (RUÓTULO, 1998, p.159)

É importante ressaltar que os receptores não devem ter contato pessoal com o comunicador, pois poderia influenciar sua escolha e resposta à audiência. As respostas que os indivíduos fornecem aos conteúdos transmitidos em uma comunicação é que dão sentido para a análise dos estudos de audiência e são classificados como respostas de: exposição, recepção, atitudinais e comportamentais.

\section{Perspectivas da exposição}

As perspectivas da exposição interessam-se na decisão do indivíduo pela sua escolha em consumir o conteúdo dos meios de comunicação podendo ser pela leitura de artigos, ida ao cinema ou a audiência a programas de rádio ou televisão. A exposição divide-se em "perspectiva estrutural" e os "usos e gratificações".

\section{Perspectiva estrutural}

Observa a audiência como um aglomerado de indivíduos que são entendidos como consumidores dos produtos dos meios de comunicação. O mapeamento da audiência é o foco central em termos de tamanho e composição sócio-demográfica.

\section{Usos e gratificações}

O interesse dessa perspectiva está no entendimento da decisão do receptor na escolha do meio e no conteúdo da comunicação e tenta-se explicar por que um indivíduo passa horas vendo $\mathrm{TV}$, ouvindo rádio e lendo algum jornal. Essa teoria tem os seguintes fundamentos:

1- O receptor é ativo e busca os meios de comunicação e os conteúdos que melhor atendam às suas necessidades e desejos.

2- Os motivos que levavam à escolha dos meios e conteúdos estão sujeitos a inúmeras influências psicológicas, sociais, ambientais e conjunturais.

3- A exposição aos meios compete com outras formas potencialmente capazes de satisfazer (gratificar) aos mesmos motivos. O indivíduo poderá escolher expor-se aos meios ou 
procurar outras formas de gratificação não relacionadas aos meios de comunicação. (RUÓTULO, 1998, p. 162)

\section{Perspectivas da recepção}

As perspectivas da recepção enfocam o entendimento das respostas da audiência após a exposição, pois elas consideram a audiência como uma rotina, quase automática, e prática social não estruturada e com baixo grau de envolvimento. Essas perspectivas visam também receber a construção subjetiva de significados decodificados pelos receptores. É a avaliação da interpretação dos conteúdos das mensagens enviadas.

As perspectivas da recepção utilizam os estudos críticos, que tomam como base os conteúdos da comunicação, para obter o entendimento das respostas dos receptores pelos sentidos/significados políticos pela extração que fazem dos meios de comunicação e a interpretação que fazem desses conteúdos.

Para estudar a recepção com base psicológica, utiliza-se o interacionismo simbólico, pois este verifica a ocorrência do conteúdo e da decodificação das mensagens, dentro do contexto interativo de comunidades interpretativas desestruturadas, pois não há composição familiar, ocupacional ou de classe social. Mas não se espera que ocorra similaridade de interpretação entre os indivíduos da mesma família ou classe social por não formarem comunidades interpretativas. O que existe é um nexo social individual que dá ponto de partida para a decodificação e formam os significados dos meios de comunicação. Cada indivíduo constrói seu entendimento de mundo como sua realidade simbólica.

Complementando as perspectivas da recepção, tem-se a perspectiva da construção cultural. É a mais moderna e tem base humanista. Ela reflete sobre a participação dos meios de comunicação, como esforço coletivo, para a interpretação da realidade social pelas manifestações simbólicas na arte, na literatura, no mito ou nos meios de comunicação, por formarem parte do processo cultural que influencia os indivíduos.

Ruótulo assim esclarece:

A comunicação humana é o processo básico vital através do qual os indivíduos constroem os significados culturais coordenando suas linguagens e concepções de mundo. A comunicação é vista como essencialmente dialógica; (...) Os meios de comunicação formam um fórum facilitador do diálogo, um espaço no qual a cultura é construída, modificada e reconstruída... (RUÓTULO,1988, p. 165) 
$\mathrm{Na}$ passagem citada, o autor descreve a comunicação como formadora de cultura. $\mathrm{Na}$ perspectiva da construção cultural, a comunicação é um elemento de formação de acordo com a realidade de cada grupo de indivíduos construída a partir do diálogo. E o seu papel fundamental é buscar as interpretações pela análise das ações dos indivíduos dos grupos. Mas é importante ressaltar que não existe interpretação única, pois cada receptor encontra significados próprios que podem diferir do significado do emissor. Assim, quanto mais conteúdos forem produzidos pela indústria cultural maior será a possibilidade de haver modificações de significados para que o receptor se aproxime mais da própria percepção.

\section{Perspectivas atitudinais}

O objeto de observação das perspectivas atitudinais está na habilidade de influência dos meios de comunicação sobre a opinião dos receptores. A opinião traduz as atitudes do indivíduo em agir de uma determinada maneira, pois ela não é exatamente o comportamento, mas sim uma etapa anterior a ele. É uma predisposição ou propensão ao comportamento, pois, na maioria das vezes, poderá haver concordância entre a atitude e o comportamento, e isso pode estar relacionado com a influência sofrida pelos meios de comunicação.

A área principal de estudo e verificação das perspectivas atitudinais é a da Opinião Pública e do comportamento político, pois a difusão de meios eletrônicos com as novas tecnologias fez dos meios de comunicação o agente principal no qual se forma e se modifica a Opinião Pública. Para melhor verificar as perspectivas atitudinais, é importante que se conheça as perspectivas de persuasão e a teoria da pauta.

\section{Perspectivas de persuasão}

$\mathrm{Na}$ década de 30, os teóricos da comunicação acreditavam que os meios de comunicação tinham o poder de mudar, de forma direta, as opiniões dos receptores. Já na década de 50, as concepções teóricas de persuasão voltaram-se para os efeitos indiretos dos meios e isso prevalece até a atualidade na tradição norte-americana, pois essas teorias buscam os fatores de credibilidade e 
atratividade da mensagem em relação ao apelo emocional do receptor pelo seu nível de conhecimento prévio do assunto em questão, o que pode influenciar indiretamente sua opinião.

\section{Teoria da pauta}

A Teoria da Pauta, também conhecida como Agenda Setting, surgiu em decorrência da falta das perspectivas de persuasão por não observarem as mudanças de opinião dos receptores. A pauta é uma teoria atitudinal e afirma que as opiniões dos receptores não mudam pelos meios de comunicação, pois acredita que o objetivo deles é o de colocar na pauta dos receptores as suas preocupações em relação aos assuntos sobre determinados temas. Os meios de comunicação influenciam na medida em que os temas de suas pautas fazem transparecer opiniões que existem na composição atitudinal dos receptores. Nesse contexto, ocorreria a estimulação de certas opiniões em relação à supressão de outras opiniões.

\section{Perspectivas comportamentais}

A conduta do indivíduo após a exposição aos conteúdos da comunicação é o que motiva e origina a verificação das perspectivas comportamentais. Nesse enfoque, o receptor é tido como agente passivo e suas reações são interpretadas como evidência dos efeitos dos meios de comunicação. Nesse caso, os conteúdos dos meios de comunicação são tidos como as causas da mudança de opinião no comportamento em questão. As perspectivas comportamentais propõem a existência do condicionamento e da modelagem.

\section{Perspectivas do condicionamento}

O condicionamento do comportamento do receptor trata da relação de causa e efeito, mas isso não afeta todos os receptores com a mesma intensidade. PROETTI (2003), autor deste artigo, define causa e efeito da seguinte forma:

CAUSA: é o fenômeno que, de forma suficiente, provoca o aparecimento de outro fenômeno e antecede o segundo fenômeno chamado efeito. 
EFEITO: é o resultado do fenômeno causa e é o segundo fenômeno consequente do primeiro denominado causa, encontrando nele a sua razão de ser. (PROETTI, 2003, p. 9798)

A Teoria do Condicionamento visa especificar os elementos essenciais como condições que devem se apresentar para que ocorra o efeito que, nesse caso, é o comportamento. Pode-se exemplificar como efeito a exposição do conteúdo de violência na televisão sobre o comportamento agressivo dos receptores.

\section{Perspectivas da modelagem}

Focaliza-se na conduta do receptor e também é considerada como uma perspectiva comportamental, mas tem uma característica própria que a diferencia: propõe a existência de um estágio intermediário que se localiza entre a exposição aos meios de comunicação e a manifestação do comportamento, e tem como princípio fundamental o processo de aprendizagem observacional por meio de modelos (personagens e situações que os envolvem). Essa aprendizagem tornar-se-á parte dos conhecimentos e habilidades que serão usados quando surgir situações semelhantes para que se possam manifestar comportamentos resultantes.

Assim, quanto maior a qualidade e a capacidade dos meios de comunicação, maior será o seu poder de ensinar.

\section{PARTE II}

\section{O problema estudado na monografia}

Nesta parte, será abordado o problema do trabalho com fundamentações efetuadas a partir do referencial teórico (parte I).

Em primeiro plano, faz-se necessária a exposição do problema gerado para o estudo: “Como alcançar (ou ultrapassar) as expectativas dos receptores na comunicação?”

Discorreu-se neste trabalho acadêmico sobre vários aspectos importantes: o crescimento de audiência, a linguagem dos veículos de comunicação, a satisfação dos anseios dos receptores, juízos 
de valores, a influência dos meios de comunicação, a sociedade de comunicação de massa, o poder de influência dos líderes de massa, os efeitos da tecnologia moderna na comunicação, os problemas que causam frustração nos receptores, a persuasão, o interesse em obter informação, a exposição seletiva e, por fim, as considerações dos estudos de audiência pelas suas perspectivas de recepção.

Alcançar as experiências dos receptores está nos objetivos de qualquer fonte emissora de comunicação, pois não haveria razão de ser se assim não o fosse: escrever por escrever, criar por criar, falar por falar e transmitir por transmitir não teriam coerência lógica.

O problema em questão foi gerado com o objetivo de estudar e entender as formas de recepção em relação à fidelidade da comunicação e o interesse que se pode conseguir dos receptores. O referencial teórico (parte I) reforça de forma significativa este estudo. Para se entender as expectativas do receptor deve-se pensar o que ele espera, o que ele deseja que aconteça ou, ainda, pode-se questionar: por que ele se expõe a uma ou mais comunicações e, se o emissor tem alguma noção do que o receptor espera para ver e ouvir. Inicialmente, é preciso rever alguns conceitos: a formação do juízo sobre o valor de uma ideia, pela sua comparação com juízos predefinidos pelo receptor. Isso facilita alcançar as expectativas quando se tem a aceitação da comunicação enviada. Outro aspecto importante, que deve ser levado em consideração, é a influência da mensagem comunicada pelo meio correto podendo-se obter maior qualidade na fonte. Isso permitirá obter um sentimento positivo do receptor em relação à mensagem transmitida e contribuir para que se possa alcançar a expectativa, tanto do receptor, quanto do próprio emissor.

A maior dificuldade, talvez, para que se possa alcançar a satisfação plena - expectativas dos receptores, seja a mensuração, ou seja, a medição, a quantificação da expectativa dos receptores, o quanto cada indivíduo espera de uma comunicação. É essencial que se reflita sobre a formação do processo de produção dos meios de comunicação em relação às crenças e valores que são selecionados como produtores de informações aos efeitos de audiência pelo estudo das atitudes e comportamentos dos receptores.

Quando se trata de alcançar as expectativas dos telespectadores, por exemplo, os meios de comunicação têm canais com maior riqueza de transmissão de mensagens como a televisão e o cinema. No caso de filmes, os trailers contribuem para levar comunicação aos telespectadores com imagens e sons que estimulam a audiência; porém, se o filme não corresponder às expectativas, ou seja, o que os receptores esperavam do filme pelo que viram quando expostos ao trailer, poder-se-á obter menos do que eles tinham de crenças e valores, pelo que já tinham visto no trailer, causando 
frustração como efeito. As formas como as pessoas veem e compreendem o mundo ajudam para a formação de seus conceitos próprios.

Dessa forma, seus conhecimentos prévios colaboram para a recepção da comunicação e facilitam a ação dos meios de comunicação. Essa ação pode ser considerada como a causadora do aumento da audiência. As novas tecnologias eletrônicas reforçam o poder de transmissão de mensagens e atingem a massa formada pelos indivíduos. Cada um deles tem seus anseios e desejos que formam suas expectativas; à medida que elas vão sendo alcançadas, surge o estado de estímulo - motivação - e enquanto esse estado emocional prevalecer, haverá o interesse em continuar a exposição para a recepção da comunicação e, consecutivamente, se obterá o aumento da audiência.

Mauro Wolf ${ }^{33}$ (1985) enfocou a importância dos meios de comunicação em relação à eficácia das mensagens para se obter persuasão com a estrutura da mensagem em relação ao uso desses meios. Relacionando-se à afirmação de Wolf com o estímulo - causa - e o processo formado pela personalidade (processos psicológicos), obter-se-á a resposta (efeito). Se a mensagem foi formulada com eficácia e atingir/influenciar emocionalmente os indivíduos, alcançaram-se, assim, os objetivos da comunicação pelo ponto de vista do emissor persuadindo-se, então, os receptores.

A persuasão pode ter sido facilitada se o receptor se sentiu estimulado/motivado em receber a comunicação. A possibilidade de a expectativa ser atendida existe também e, nesse caso, houve a concordância do espectador, pois esperava, parcial ou integralmente, o teor do conteúdo. Nesse contexto, houve a exposição seletiva do receptor e o interesse em obter a informação.

Outros fatores se fazem importantes para se entender e completar algumas explicações sobre o alcance das expectativas; são eles: a percepção e a memorização seletiva. Só haverá memorização se houver interesse pela mensagem; o interesse pressupõe estímulo e este permite a continuidade da recepção e a fixação das mensagens aos valores individuais próprios. Consecutivamente, haverá a memorização dos elementos que se assemelhem às suas opiniões. Dessa forma, obter-se-á o alcance de expectativas. Quando os elementos da mensagem realmente motivam acima do esperado, ultrapassam-se as expectativas.

Ultrapassar as expectativas das pessoas não é uma tarefa fácil, pois elas são compostas por elementos introspectivos de difícil interpretação. Essas dificuldades surgem à medida que o emissor não conhece os receptores. Para exemplificar melhor, pode-se pensar na transmissão de um programa de rádio em que o locutor não conhece e nem tem contato com os ouvintes.

\footnotetext{
${ }^{33}$ WOLF, Mauro. Teorias da comunicação. Lisboa: Presença, 1987. p. 28
} 
Se houver qualidade de transmissão das mensagens, capacidade técnica - equipamentos clareza oral, precisão das palavras e assuntos importantes, certamente haverá audiência; e se esses assuntos fizerem com que os ouvintes se exponham com atenção, se interessem e gostem da transmissão, percebendo que são importantes, agradáveis e úteis, sentirão motivação por terem suas expectativas atendidas, ou até ultrapassadas, e decidirão por permanecerem ouvintes diários da programação da rádio, ou só naquele horário.

Dessa forma, as necessidades dos ouvintes podem ser satisfeitas gerando motivação, pois eles decidiram que o emissor - rádio - transmitia o que lhes traziam (mensagens) com conteúdos úteis (usos e gratificações). Nota-se, então, a consonância cognitiva pela coerência lógica em relação ao que eles acreditam, entendem e percebem como conhecimento de mundo. Observe a citação a seguir:

\begin{abstract}
...O foco central da teoria de usos e gratificações é o conjunto de motivações que levam o telespectador a expor-se à televisão. Não se pergunta o que a televisão está fazendo às pessoas, mas sim o que as pessoas estão fazendo com a televisão. ( ) A formulação da teoria de usos e gratificações afirma que as condições sociais e psicológicas do indivíduo dão origem à sua motivação de ver televisão para preencher determinadas necessidades. Essas necessidades aparecem a partir das situações vividas pelos indivíduos na sua experiência diária. As situações do quotidiano são, portanto, a gênese das gratificações na medida em que facilitam o maior ou menor envolvimento com os meios de comunicação ou que geram necessidades não plenamente satisfeitas na vida real e que são compensadas pelo uso dos meios de comunicação... (RUÓTULO, 1993, p.65)
\end{abstract}

Outro fator que ajuda a esclarecer o atendimento das expectativas dos receptores para a formação de audiência é o entendimento, aceitação das mensagens como fator de construção cultural. Mas é preciso ressaltar que a interpretação é individual, pois cada receptor encontra significados próprios e os utiliza conforme suas necessidades. Isso se explica pelas perspectivas da recepção.

O problema em questão pode ser enfocado como um caso de competição entre diferentes emissores como, por exemplo, redes de televisões e difusoras de rádio. Para se conquistar a audiência, tanto nas TVs como nas Rádios, podem-se perceber, na atualidade, ofertas de diferentes temas e tipos de programações que buscam entreter, informar e, até, chocar as pessoas das maneiras mais criativas e apelativas possíveis. A violência, a apelação religiosa, moral e sexual são elementos que preenchem as programações televisivas e radiofônicas, na tentativa de chamar a atenção, mesmo que por impulso ou curiosidade, e manter a exposição dos espectadores e ouvintes para conseguir motivá-los e fazer com que se decidam e escolham a programação total ou parcial em 
exibição. Esses meios de comunicação de massa têm conseguido, na maioria das vezes, alcançar as expectativas dos receptores, pois nota-se que algumas programações brasileiras são mantidas por longo tempo em exibição. Pode-se exemplificar isso com os programas dominicais do apresentador Silvio Santos, do apresentador Fausto Silva, com o programa Fantástico, entre outros. Conclui-se, então, que as audiências, nesses casos, são mantidas e podem-se explicá-las e fundamentá-las de forma consoante pela Teoria de Usos e Gratificações, pois o receptor vê alguma vantagem em expor-se à programação e se satisfaz de alguma forma.

\section{Considerações finais}

Após as exposições formuladas e fundamentadas neste trabalho, faz-se necessário relembrar algumas passagens que ajudaram na reflexão do problema estudado. Mesmo que os meios de comunicação influenciem os receptores, pode-se pensar e entender que não há influências que consigam manter opiniões de modo contínuo e imutável. O ser humano pode modificar sua opinião e buscar outras fontes se assim achar necessário, ou até interessante, para sua informação, conforto, segurança e preferência.

A fidelidade pode ser parcial e durará enquanto suas necessidades e curiosidades estiverem sendo satisfeitas. Se o uso e gratificação estiverem momentaneamente contemplados, ter-se-ão alcançadas ou até ultrapassadas as expectativas, mantendo-se, também, a audiência.

Sem dúvida, cada vez mais, tem-se uma sociedade de comunicação de massa que cresce e se informa com velocidade impressionante, ocasionada pelo desenvolvimento das novas tecnologias de informação como a Internet e as redes de televisão abertas e a cabo.

Outro enfoque de importância deste trabalho se deu na passagem sobre os fatores relativos à audiência, os fatores que se referem ao interesse do receptor em obter informação na exposição seletiva, na percepção e na memorização seletiva, os quais colaboraram para se estudar e entender o comportamento e escolha dos receptores, pela visão de Mauro Wolf. Essa exposição delineou o caminho para utilizar os estudos do Prof. Dr. Antônio Carlos Ruótulo (PhD), que escreveu importante artigo sobre audiência e recepção, o qual foi de muito valor e proveito para o fechamento deste trabalho.

As fundamentações do problema aqui apresentado: "Como alcançar (ou ultrapassar) as expectativas dos receptores na comunicação?" foram beneficiadas pelas passagens de texto 
literalmente retiradas, citadas e referenciadas do artigo de RUÓTULO, publicado na Revista Comunicação e Sociedade do curso de pós-graduação em Comunicação Social da Universidade Metodista de São Paulo (UMESP).

O estudo aqui apresentado não teve objetivo de tratar o assunto com demasiada profundidade nem esgotá-lo, pois se sabe que todo estudo, sobre qualquer tema, é um início de abertura científica que dá condições para que outros pesquisadores deem continuidade em outros estudos e contribuam com suas descobertas. Esse é um dos postulados da ciência. Espera-se, inicialmente, que o presente trabalho permita essa iniciação científica e contribua, mesmo que de forma humilde, com os futuros pesquisadores e estudantes de comunicação.

Este autor pôde perceber que o assunto é relevante para os estudos de audiência e que, se levado adiante, poderá ser pesquisado de forma mais detalhada. O estudo também contribuiu para se entender algumas teorias e permitiu a adequação do tema para estudos de audiência para as novas necessidades de comunicação e tecnologias de informação na comunicação social.

\section{Referências bibliográficas}

BERLO, David K. O processo de comunicação: introdução à teoria e à prática. Trad. Jorge Arnaldo Fontes. São Paulo: Martins Fontes, 1999. 330 p.

DIMBLEBY, Richard; BURTON, Graeme. Mais do que palavras: uma introdução à teoria da comunicação. 3.ed. São Paulo: Summus Editorial, 1990. 215 p.

Dicionário completo da Língua Portuguesa - Folha da Tarde. 3. Ed. Coord. Flávio Bonfim Pestana. São Paulo: Melhoramentos, 1994.

LANE, Robert E.; SEARS, David O. A opinião pública. Trad. Álvaro Cabral. Rio de Janeiro: Zahar Editores, 1996. 200 p.

LUYTEN, Joseph M. Sistemas de comunicação popular. São Paulo: Ática, 1988. 64 p.

MELO, José Marques. Comunicação, opinião, desenvolvimento. Rio de Janeiro: Vozes, 1971. 114 p.

PROETTI, Sidney. Simplificando a lógica. São Paulo: Mil Folhas, 2003. 132 p. . Metodologia do trabalho científico: abordagens para a construção de trabalhos acadêmicos. 5. ed. São Paulo: Edicon, 2006. 190 p. 
IMPORTÂNCIA DOS ESPECTADORES, COMO FORMADORES DE AUDIÊNCIA, EM RELAÇÃO ÀS SUAS EXPECTATIVAS Sidney Proetti

RUÓTULO, Antônio Carlos Filippi. Audiência e recepção: perspectivas. Comunicação e sociedade. São Paulo: n. 30, p. 157-170, 1998. . “Tipologia dos telespectadores do ABC Paulista”.

Comunicação e sociedade. São Paulo: n. 20, p. 61-71, 1993.

WOLF, Mauro. Teorias da comunicação. Lisboa: Presença, 1987. 249 p. 